No. 4163 August 13, 1949 Philosophical Studies $1 / 6$ Essays in Niemory of L. Sisan Stebbing. (Published for the Aristotelian Sogicty.) Pp. v+156. (London : G. Allen and U (molit, Ltd., 1948.) 15s. net.

$7 \mathrm{HE}$ authord tho contribute to this neat little volume of essays combine to pay fitting tribute to a grat mind. They discharge their task all the better by abst lining from writing a commentary upon the work of Susan Stebbing. What they have done is to discuss subjects that interested her and which her keen intellect had illuminated. In this way her memory is perpetuated and her place in philosophy secured.

During a life not free from controversy, she carried many of her forays to success, though it is more than likely that, were she with us to-day, she would administer a characteristically sharp rap to some of the views so generously marshalled in her honour. Thus, within less than eight-score pages, we traverse much of epistemology, ethics, psychology and the scientific aspect of history. One neither looks for nor expects cut-and-dried conclusions; the writers proffer their garlands with a certain abandon.

Prof. Stebbing assuredly selected her targets with a refined academic glee, as, for example, in her "Philosophy and the Physicists" (1937). The thrusts she delivered seem somewhat on the harsh side; maybe they were not intended to endure. Her whole being brings into relief the difference between logic bent upon truth, and resthetics bent upon beauty. In her greatness, she lived for the former, others perhaps for the latter. But one day a 'pontiff' will arise and throw a bridge across the narrows; when that happens, the sheer weight of her thought will help to anchor it well and truly on her territory.

F. I. G. RAwLINS

\section{Outline of Historical Geology}

By Dr. A. K. Wells. Second edition, revised with the assistance of Dr. J. F. Kirkaldy. Pp. xi+ 356. (Londonf Thomas Murby and Co., 1948.) 25s. net.

'HE new ofion of Dr. A. K. Wells's "Outline of
Historical Geology", which succeeds the first
editionter a lapse of ten years, has been revised
and geatly expanded, with the assistance of Dr.
J. Kirkaldy. The text now runs to 340 pages, in
comparison with 254 in the original edition ; and the
number of illustrations has been considerably increased
by means of text figures specially drawn for the
authors.

Apart from bringing the subject-matter up to date in the light of recent research, the scope of the work has been deliberately widened. Originally intended for the general reader and first-year undergraduates, the new edition is designed to meet the needs of students reading for degrees. While still stressing the philosophical rather than the factual aspects of the subject, readers who may wish to pursue particular topics in more detail have been provided for by the addition, at the end of nearly every chapter, of short lists of selected references.

The nature of the subject is such that there is not infrequently room for differences of opinion among experts, and, although attention has been directed to the existence of such differences, detailed discussions of controversial matters have been avoided. This is as it should be in a general text-book, and there is no doubt that this work forms an excellent introduction to British stratigraphy.
Teaching for Trades

A Guide to the Training of Workers in Manuel Trades. By Alfred W. Tajinins. Pp. xi+70. (London: Sir Isaac Pitman anghoons, Ltd., 1948.) 8s. 6d. net. $D$ URING the last ten years there has been a marked Shd significant increase in the amount of atten on given in Britain to vocational training. This can be partly accounted for by the introduction of the Ministry of Labour and National Service "Training Within Industry" scheme during the War to meet the labour demands of new and rapidly expanding factories. As a basis, certain elementary rules were prescribed for training foremen and other supervisors, and these were grouped into courses known as "Job Instruction", "Job Methods" and "Job Relations". The courses were based on wellknown principles in educational psychology and, although necessarily limited in application, have met with a considerable amount of success.

Mr. Hawkins is obviously well-versed in "Training Within Industry" principles and, in this useful little book, uses the practical experience he has gained to elaborate methods of training which would be suitable for those who are concerned with the training of teachers of vocational and craft subjects. To the qualified teacher the book will offer little with which he is not already familiar ; but it should prove most acceptable and useful to all the thousands of men and women who act as part-time teachers in technical and vocational institutions. The author does not waste words and, in quite a short space, gives some valuable advice on how to plan a curriculum, the organisation of training schemes and the keeping of records.

\section{Farming for Industry}

By R. O. Whyte. (Todd Reference Library.) Pp. $160+16$ plates. (London: Todd Publishing Group, Ltd., 1948.) 7s. $6 d$. net $A$

THE three great claims on the use of agricultural fin are the production of crops for human cons mption, animal fodder and industrial purposekl. Since the Second World War, attention hap of. lecessity been chiefly directed to increasing foo production; but a proper balance between these three objectives must be developed if land is to be used to full capacity and the wastage that has so often occurred in the past is to be avoided in the future. This is more likely to be achieved if the needs of industry are better understood. In the present volume the author gives much useful inform. ation as to the sources of supply, consumption and technical processes connected with the production of such commodities as leather, vegetable oils, tobacco, and textiles from animal and plant fibres.

In some cases the problems of the industry are mainly agricultural, in others economic or sociological ; but, throughout, emphasis is laid on the desirability of the multiple use of all parts of the plant or animal where feasible and of the need for raising agricultural standards and improving technique to the mutual benefit of both farmer and industrialist. The book will also appeal to those interested in the origin of articles used in everyday life. From by-products of the dairy and animal industries, plastics, glues and cosmetics can be manufactured, and though of little commercial importance, fibres are obtainable from such widely differing sources as milk, soybeans, groundnuts and seaweed. The illustrations add considerably to the value of the book. $K$. W. 